South Korea, also known as the Republic of Korea (ROK), is a remarkable country in many ways. It survived the Korean War, supported by American military assistance. It successfully transitioned to democracy after nearly 40 years of authoritarian government. South Korea now boasts a strong economy that joined the trillion-dollar club of world economies in 2004. ${ }^{\text {i }}$ The South Korean wave (hullyah) looks unstoppable with its success in Asia and around the globe. But in spite of its impressive résumé, the ROK has been criticized for its handling of diplomatic relations with the Democratic People's Republic of Korea (DPRK), after its northern neighbor's nuclear tests caused a shutdown of the Kaesong economic zone in April 2013. Debates about an appropriate solution to the diplomatic impasse became a common topic in academia and the media. Many pundits pointed to the ROK's soft power as a potential response to Northern aggression, while ignoring the full possibilities and operational mechanisms of this soft power.

This paper argues that South Korea has failed to effectively exercise its soft power capability on the North Korean territory due to the DPRK's profoundly isolationist nature, manifested in the regime's draconian political and economic policies. It claims that the ROK's ability to exercise its soft power in dealing with North Korea is undercut by China, because of the DPRK's central geopolitical significance for Beijing. The paper is structured in five sections. The first section briefly discusses soft power as a concept and presents the theoretical framework for the analysis. The second section discusses the ROK's soft power resources. The third and fourth sections discuss the ROK's approaches with regard to North Korea, and explain why soft power failed to effectively handle the North Korean threat. Finally, the paper concludes that a soft power approach will not contain the North Korean threat due to the ROK's failure to penetrate the DPRK's isolated system, and because of its geostrategic importance to China as a buffer zone.

\section{THEORETHICAL FRAMEWORK}

Harvard academic Joseph Nye coined the term of soft power in his book Bound to Lead in 1990. While the concept has generated extensive academic discussions, it has also resulted in the misuse and misinterpretation of the term. Establishing a solid framework for the concept of soft power and its operational mechanisms is crucial for this paper's argument. Nye defined soft power as an "ability to affect others through the co-optive means of framing the agenda, persuading, and eliciting positive attraction in order to obtain preferred outcomes". ${ }^{1}$ Before Nye elaborated his concept, E.H. Carr 
STATES ATTAIN SOFT POWER

RESOURCES BY PROJECTING BEAUTY,

BENIGNITY, AND BRILLIANCE

discussed a similar idea - power over opinion - in his distinguished work The Twenty Years' Crisis. He states that power over opinion is "not less essential for political purposes than military and economic power". ${ }^{2}$ This can be seen as an initial version of the concept of soft power, later advanced and brought to academia's attention by Joseph Nye. ${ }^{\text {ii }}$ Conversely, other scholars see it as simple marketing, or worse, propaganda. For example, Christopher Layne claims that "soft power is a means of marketing" a certain state's brand, which can be measured by opinion polls. ${ }^{3}$ The term has been misused and misinterpreted to the extent that it has started to be used to refer even to culture and humanitarian aid. Critics claimed that "soft power now seems to mean everything," as it can refer to concepts as disparate as multilateralism, democratic values, and markets. ${ }^{4}$ However, such a simplistic definition overlooks soft power's significance and mechanisms. Nye addresses this criticism by stating that the authors confuse "the actions of a state seeking to achieve desired outcomes with the resources used to produce those outcomes". ${ }^{5}$ Nye suggests, for example, that attractive culture and democratic values increase soft power resources, but the fact that a certain state's culture and values are appealing does not mean the state automatically projects its soft power. Furthermore, Nye states that "whether one or another type of resource produces power in the sense of desired behavior depends upon the context". ${ }^{6}$ Both context and actions matter: the failure to make a judicious decision with regard to the Vietnam War resulted in a military disaster for the United States that damaged the American economy and harmed the nation's image abroad.

It is important to remember that soft power is an important option in the foreign policy toolkit that should be utilized when the context is appropriate. Nye admits that "soft power is not the solution to all problems". ' Other forms of power are hard and economic power. Hard power refers to the use or threat of military force. Hard power resources are relatively easy to estimate by calculating the size of a country's conventional military forces. It can operate through inducements ("carrots") or threats ("sticks"). ${ }^{8}$ Specific examples of the exercise of hard power include: conducting military operations, backing up coercive threats, protecting allies, conducting peacekeeping missions, or providing different forms of assistance, such as training military personnel in other countries. ${ }^{9}$ Economic power, on the other hand, is more complicated and intricate because it can function as both hard and soft power. In the simplest terms, it means rewarding states with economic benefits for good behavior, and punishing them with sanctions for not complying. When economic sanctions undermine the livelihoods of 
people on the receiving end, they can be considered an exercise of hard power. Yet economic success that attracts other states to a particular type of economic model may boost that state or states' soft power. For example, the European Union model of economic integration has attracted states from the former Eastern Bloc to change their domestic policies and structures in order to join the union. ${ }^{10}$ Thus, the context for the deployment of a certain type of power must be carefully examined. In Libya, for example, diplomatic resources and economic sanctions had only limited results. Gaddafi's 40-year-old regime was not eliminated and replaced with the Transnational National Council until NATO executed an air campaign in 2011. iii Failure to understand the context and to act accordingly using the appropriate tools can result in a strategic fiasco.

This paper defines soft power as the ability of state A to persuade state B through projecting "three B's" (benignity, beauty, and brilliance) to do something, dependent on successful execution during transmission and reception stages. I will use Alexander Vuving's and Kondo Seichi's conceptual frameworks in order to illustrate the necessary features for successful soft power deployment. According to Kondo Seichi, the deployment of soft power consists of four stages: resources, transmission, reception, and outcome. He compares these stages of deployment to those of missiles: one needs to first possess missiles (resources) with the appropriate delivery mechanism (transmission), able to penetrate an enemy's territory (reception), and destroy targets on the enemy's terrain (outcome). ${ }^{11}$ In addition, Kondo states that, "With malfunction at any stage, power cannot determine the outcome". ${ }^{12}$ In other words, in order for soft power to work, every stage, particularly transmission and reception, should be executed with caution and foresight.

Alexander Vuving further explains that "softness" is attained by the three "power currencies" of "beauty, benignity and brilliance". ${ }^{13} \mathrm{Be}-$ nignity describes an unselfish non-threatening behavior to other actors which "produces gratitude and sympathy" in response. ${ }^{14}$ Switzerland is a classic example: much of its soft power resources derive from its diplomacy's emphasis on neutrality, rather than alliance building. Brilliance, in turn, produces admiration due to high performance and one's success. ${ }^{15}$ China's economic miracle, for example, has been one of the biggest sources of its soft power. ${ }^{\text {iv }}$ Many states strive to emulate Chinese economic success by following the "Beijing Consensus" model. ${ }^{v}$ Beauty refers to the "resonance that is evoked when you represent ideals, values, causes, or visions" ${ }^{16}$ For instance, the European Union's commitment to peace and democratic values has made it one of the biggest soft power "heavyweights." In sum, states attain soft power resources by projecting beauty, benignity, and brilliance. Once these resources are attained, soft power can be projected following Kondo's stages of transmission and reception, with the outcome dependent on the success or failure of these stages. ${ }^{17}$

\section{ROK'S SOFT POWER RESOURCES}

South Korea's miraculous economic development and rapid democratization gave it crucial soft power resources. Indeed, this economic and democratic success has given the ROK the ability to attract other states through Vuving's concept of brilliance. Embracing democracy and democratic values secured it respect and prestige from like-minded states. Culturally, the Korean wave has influenced dozens of countries from Asia to South America. In many respects, Gangnam Style "infiltration" into western markets brought K-pop to light and boosted its popularity. South Korean dramas and movies have swept the globe, and have given South Korea an upper hand in its soft power rivalry with Japan and China despite its late start. ${ }^{\text {vi }}$ Two crucial features that contribute to the Korean wave's attractiveness and potential expansion is its cultural proximity to China and Japan and, more importantly, the fact 
that Korean products are free from historical antagonism. ${ }^{\text {vii }}$ ROK's assistance to Haiti in 2010 further demonstrated how the combination of military and economic resources can increase a state's soft power and international prestige. ${ }^{\text {viii }}$ In addition, by 2010 ROK had established 35 King Sejong Institutes for Korean language and culture, and has plans to increase their number to 150 worldwide by $2015 .{ }^{\text {ix }}$ Co-hosting the 2002 World Cup with Japan and reaching the semi-finals reinforced South Korea's position in the world. ${ }^{\mathrm{x}}$

It is important, however, to keep in mind that the above activities and attributes only cultivate soft power resources; they cannot by themselves deliver desired outcomes. Having many resources does not necessarily mean that a state can proceed to the further stages in Kondo's sequence of soft power deployment namely, transmission and reception to produce a desired outcome. Moreover, having an abundance of soft power resources does not make its usage necessary. Policymakers need to calculate whether the 'deployment' of soft power can bring the desired results in a specific context.

\section{Deploying Soft Power in North KOREA}

From the onset of the Korean War until the election in 1988 of the first civilian presi- dent, Roh Tae-woo, the ROK's foreign policy was influenced by Cold War logic. The United States supported South Korea militarily and economically while Soviet Union propped the North Korean regime. In 1988, Roh Tae-Woo articulated Nordpolitik policies that had important domestic and international implications. The policy included warming relations with eastern-bloc states, China, and the Soviet Union while easing tensions with North Korea. As a result of these policies, China became one of South Korea's most important trade partners. It

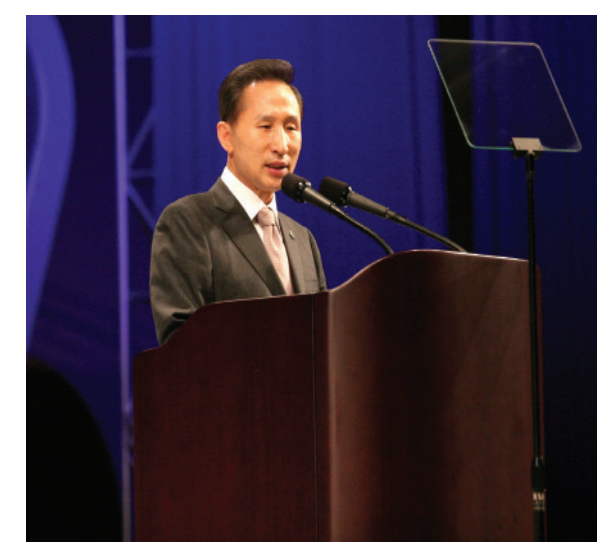

FORMER SOUTH KOREAN PRESIDENT, LEE MYUNG-BAK. SUCCEEDED BY PARK GUEN-HYE IN FEBRUARY 


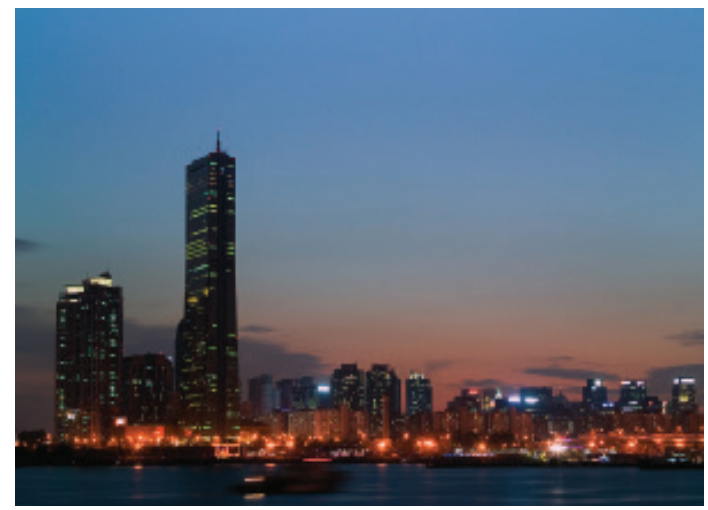

is noteworthy that, although Nordpolitik was framed as a foreign policy initiative to improve relations with North Korea and move towards reunification, it also enormously boosted the legitimacy and popularity of the new, democratically elected president.

Economically, President Kim YoungSam (1993-1998) undertook a series of labor and chaebol reforms, and other financial reforms that significantly improved the economy. ${ }^{x i}$ By 1993, the South Korea's economic miracle was fast being realized through development and industrialization. ${ }^{\text {xii }}$ Subsequently, President Kim Dae-jung articulated the Sunshine policy in 1998 that lasted until the 2008 election of conservative President Lee Myung-bak. Under the Sunshine policy, the ROK shifted its approach from a hostile hardline policy to reconciliation and cooperation with the North. ${ }^{\text {xiii }}$ Although the initiative was successful in securing a Nobel Peace Prize for Kim in 2000, and getting North Korea to the negotiation table during the Korean summit meeting in Pyongyang in 2000, it failed to achieve the desired concrete result - North Korea's rejoining the Nuclear Nonproliferation Treaty (NPT). ${ }^{\text {iv }}$

Many experts have voiced critical views about the manner in which South Korea utilized its soft power. For example, Sarah K. Yun, the Director of Public Affairs and Regional Issues for the Korea Economic Institute, claims
SEOUL, THE POLITICAL AND CULTURAL CENTER OF SOUTH KOREA'S SOFT POWER that "in order to effectively employ soft power, Korea should specify its goals and desired outcome". Similarly, Geun Lee states that "[South] Korea's soft power capacity is still very limited, $[\ldots]$, because Korea has not been interested in developing and applying soft resources to produce influence in the region and on the global stage". ${ }^{18}$ Such criticisms, however, ignore the mechanism of soft power influence. A country can specify its goals for soft power, but it does not mean that it can project it. The American goal during the Vietnam War was clearly stated and specified: winning the war against communist North Vietnam. However, this did not make the projection of soft power more effective. South Korea should indeed deploy soft power in dealing with the North, but it cannot simply transmit it to Pyongyang. The DPRK's dedication to isolating itself from the world impairs the transmission and reception phases of soft power, making the effective exercise of a soft power approach improbable. The issue is not that South Korea does not have enough soft power resources (it has them in abundance); rather, it is the transmission phase that remains a stumbling block. The ROK has been active and aware in enlarging its soft power resources, and employing them wherever possible. However, the DPRK's regime has sought to seal its borders from possible penetration of K-pop and Korean dramas that would reveal the ROK's 


\section{FOR THE DPRK'S LEADERSHIP, THE MAIN CONCERN REMAINS ITS POLITICAL SURVIVAL RATHER THAN LIBERALIZING THE ECONOMY OR RELAXING ITS LAWS}

economic and political success. Consider the fact that possession of a tunable radio has been a crime in North Korea since the late 1950's. All legally sold radios must be purchased from authorities and tuned to the official channels. ${ }^{19}$ The right to use the Internet - a distorted and tightly controlled official version-is reserved for elites and is unavailable to average citizens. The biggest deterrence mechanism for possession of any forbidden materials is the sentencing to labor in gulags, a Stalinist relic that the DPRK has preserved in the $21^{\text {st }}$ century.

For better or worse, non-state actors and individuals can also seek to exercise soft power. Non-state actors' involvement had destabilizing effects on the Korean Peninsula in 2012, when South Korean activists launched "balloon attacks" on the North. These balloons contained propaganda messages, as well as more tangible items like socks, cash, and medicine. Despite these South Korean activists' expressed desire to help their semi-compatriots, and to reveal the lavish lifestyles of North Korea's elite, their attempts to project soft power with balloons have ultimately been counterproductive. President Lee Myung-bak sent police forces to prevent the unauthorized soft power projection. At the same time, another group of activists criticized the balloon campaign for instigating conflict between the Koreas. ${ }^{\mathrm{x}}$ In response, the DPRK launched a counterattack with its propaganda.
But North Korea also took it one step further and threatened to substitute bombs for the leaflets in the future. ${ }^{\text {xvi }}$ Such soft power deployment by non-state actors highlights the significance of the hostile territory and the context in which it is exercised.

The unwillingness of North Korean leaders to reform the economy, even on a limited scale, demonstrates the nature of the regime's commitment to isolate itself and prevent information leakages that undermine the ROK's ability to transmit soft power. For the DPRK's leadership, the main concern remains its political survival rather than liberalizing its economy or relaxing its laws. Therefore, economic cooperation projects like the Kaesong Industrial Complex and the rule of law are primarily political tools, and only secondarily economic and judicial. Kaesong was designed under the Sunshine policy to foster cooperation and decrease tensions between the two Koreas. Therefore, not only did it provide economic incentives for both states, but for South Koreans it also contained an optimistic political aspiration of future reunification. ${ }^{\text {xvii }}$ However, the DPRK government closed the complex in April 2013 amid an atmosphere of high political tension, and only reopened it on September 16, 2013. At the time the Kaesong complex was shut down, it hosted 123 South Korean firms and employed nearly 53,000 people, mostly from North Korea. 
HAVING CHINA

AS A POWERFUL

PATRON FURTHER

NARROWS ANY

ROOM FOR SOUTH

KOREAN INFLUENCE

ON NORTH KOREA

THROUGH SOFT

POWER

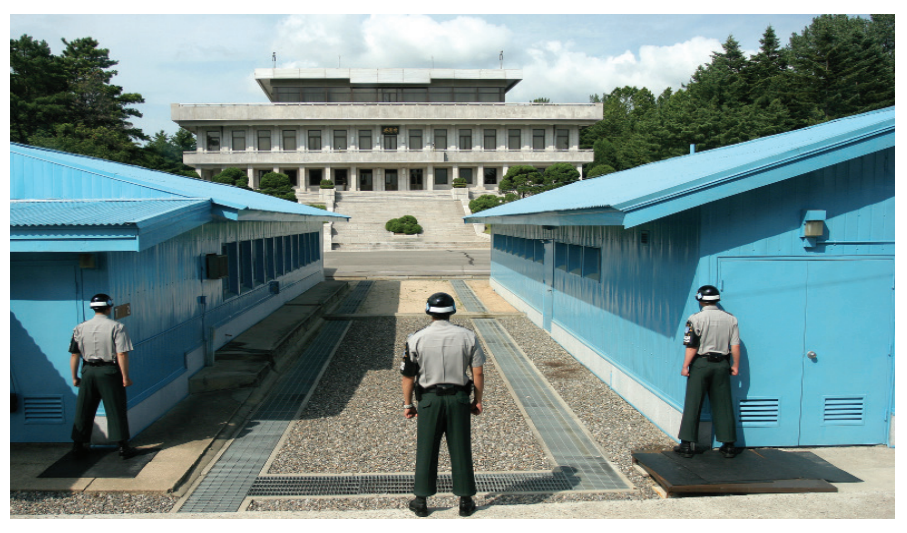

ROK SOLDIERS WATCH THE KOREAN BORDER AT PANMUMJEOM

Currently, only 70 percent of factories have resumed their production. ${ }^{\text {xviii }}$ Kaesong, for many pundits, represents a hope for a gradual transformation and economic integration of DPRK in the region. Naturally, the pecuniary side of the project has benefited both parties, but North Korea was the main beneficiary since the project provides it with scarce foreign currency. Total output reached $\$ 470$ million in 2012; before the shutdown the project as a whole generated an estimated \$2 billion in trade. ${ }^{\text {xix }}$ Sang-Young Rhyu describes Kaesong as an "experiment, testing whether North-South economic cooperation can contribute to the enhancement of political and military peace on the Korean Peninsula". ${ }^{20}$ If Kaesong serves as an experiment, then North Korea has sought to demonstrate that they will be in charge of it. When the DPRK refused an early negotiation offer from the South about reopening Kaesong, this expressed that the North would dictate the conditions to suit their economic and--more importantly--political interests. ${ }^{x x}$ The recent Kaesong affair portrayed new leader Kim Jong-un as a powerful man who indeed ruled the country. Formally nullifying the 1953 armistice on March 10, 2013 and intensifying North Korean rhetoric were already alarming, but closing down the Kaesong project gave the words substance:

North Korea's commitment to political and economic isolation undermines the ROK's ability to employ soft power, especially during the transmission and reception stages. Closure of the Kaesong project demonstrated that the cash-starved DPRK regime is willing to lose one of its most significant sources of hard currency in order to give its threats credibility. North Korea's agreement to establish the Kaesong zone can be viewed as an effort to break away from isolation; however, a five-month abeyance of the project reveals the DPRK will maintain economic relations with the ROK only as long as they serve the regime's objectives. And when they do not, the regime is quick to react. Similarly, the DPRK's inconsistent legal framework and rejection of the rule of law reveal its priority of regime power over economic development. The Sinuiju Economic zone is governed by the Basic Law of the Sinuiju Special Administrative Region. Nonetheless, the whole legal structure of the zone is sabotaged by Article 4 that declares, "The Presidium of the Supreme People's Assembly will interpret this law". ${ }^{21}$ The regime applies the same jurisdictional power to Kaesong complex - the DPRK will close and open the project when it pleases. Darren Zook notes, however, that the DPRK's failure to establish a cohesive legal framework undermines regime stability and its ability to improve the state's economy. Consequently, South Korea's soft power cannot break into such a tightly controlled environment during the transmission 
THE GEOGRAPHIC

SITUATION OF NORTH

KOREA MAKE IT BOTH

A STRATEGIC ALLY TO

CHINA AND A POTENTIAL

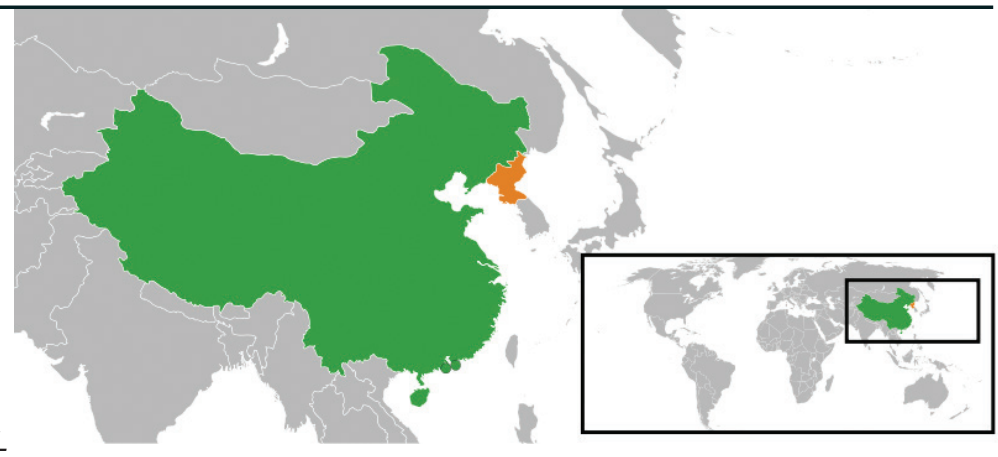

THREAT

phase.

Many scholars voice their frustration about the efficiency of soft power with regard to South Korea's failure to resolve the security threat from the North. For example, Shin WhaLee argues that, in order to achieve desired outcomes in dealing with North Korea, Seoul needs to be firm "in demanding greater openness and reciprocity from Pyongyang". ${ }^{22}$ However, such openness and reciprocity from the DPRK is unlikely, judging from its past behavior. Even when the now-defunct Six-Party talks (between the two Koreas, the United States, China, Russia, and Japan) addressing nuclear disarmament were active, the majority of the observers agree that the DPRK failed to honor its promises. Even after the other states provided food and energy, albeit in a delayed manner, North Korea still refused to join the NPT and allow International Atomic Energy Agency (IAEA) observers back into the country.

Nevertheless, some scholars and policy-makers believe that South Korea should continue its efforts to influence the North using soft power. For example, Andrei Lankov suggests that South Korea should initiate student exchange programs and spread information about prosperous lifestyles in South Korea through radio channels, documentaries, and Korean dramas drawing a parallel with the American Cold War approach towards the USSR. ${ }^{23}$ However, comparing the DPRK to the Soviet Union and attempting to apply similar educational and informational solutions ignores and misrepresents the realities of the two states. Socioeconomic conditions and the state's ability to influence people's mentality through propaganda are incomparable. In 2008, a survey of refugees living in Seoul concluded that 75 percent of North Korean defectors do not express negative sentiment for Kim Jong-il. Another set of interviews revealed that only 9 percent of North Korean refugees mention political reasons for fleeing the country, while 55 percent explain that their decision to leave the DPRK was due to a lack of sustenance. ${ }^{24}$ Consequently, the North Korean ability to influence citizens' mentality appears far greater than that of the former USSR.

\section{The China Factor and RoK's SOFT POWER}

Another major obstacle to South Korea's successful soft power projection is North Korea's geostrategic significance to China as a buffer zone. For China, North Korea presents a difficult strategic challenge: Beijing needs to fulfill its promises of being a "responsible regional player" and enforcing international sanctions on the DPRK while also maintaining stability on the Korean Peninsula. David Shambaugh argues that "preventing collapse [of North Korea] 
DESPITE CHINA'S CLEAR

IRRITATION AND CONCERNS

OVER ITS NEIGHBORING

TROUBLEMAKER, IT ONLY

OCCASIONALLY SHOWS ITS

FRUSTRATION WITH THE

NORTH KOREAN REgime and

PUNISHES IT ONLY WHEN THE

DPRK PROVOKES REGIONAL

INSTABILITY

is Beijing's bottom line because collapse would have enormous tangible human and economic consequences for China, not to mention the intangible political impact of another failed Communist state" ${ }^{25}$ North Korea provides a necessary buffer from the U.S. military presence in South Korea. Moreover, the refugees that would cross the border into China should North Korea collapse would damage Chinese internal stability. China thus finds itself in a complicated position where its policymakers need to balance the Chinese image of a responsible world player against buttressing the Kim dynasty.

The PRC is at a challenging crossroads when it comes to dealing with its unstable neighbor. For example, China refused to censure North Korea after it sank the South Korean warship Cheonan in 2010 leaving 46 sailors dead. In spite of overwhelming evidence that a North Korean torpedo caused the sinking, China stood by the DPRK amidst escalating international criticism. ${ }^{x i}$ However, in the wake of North Korea's threats to attack the ROK and United States in 2013, China distanced itself from its communist ally and joined the international community in passing economic sanctions on the DPRK. xxii To back up its rhetoric, the Bank of China closed down the North Korean credit line until it begins engaging the region as a "responsible stakeholder." xxiii China's seemingly contradictory policy moves demonstrate the difficult tightrope it must walk when it comes to North Korea.

The China-DPRK relationship underscores the point that even economic power is an insufficient persuasion tool because of the DPRK's commitment to political survival. For North Korea, China remains an indispensable ally and economic partner. In addition to Chinese aid, the DPRK's dependence on bilateral economic relations has grown steadily: Sino-DPRK trade increased by an estimated 62.5 percent totaling $\$ 5.63$ billion in $2011 .{ }^{26}$ This raises the question of whether China has gained greater leverage through North Korean economic dependence to promote one of its main goals: stability on the Korean Peninsula. Nevertheless, the DPRK has on many occasions contradicted China's interests and enraged decision-makers in Beijing. For example, North Korea's first nuclear test in 2006 escalated tensions in Asia and drew worldwide condemnation as China was preparing for the 2008 Beijing Olympics. Although the test did not target China per se, it undermined China's image as an emerging leader and destabilized the region. Despite China's clear irritation and concerns over its neighboring troublemaker, it only occasionally shows its frustration with the North Korean regime and punishes it only when the DPRK provokes regional instability. For example, after North Korea's nuclear tests in 2006, China vehement- 


\section{SOFT POWER}

\section{HAS BEEN}

UNABLE TO

PENETRATE

\section{THE NORTH}

KOREAN

\section{$S H I E L D$}

ly criticized its ally, using language it usually reserves for outright enemies. Rhetorical attacks were accompanied by economic sanctions targeting the imports of luxury goods. ${ }^{27} \mathrm{But}$ Pyongyang, in turn, exploits China's strategic calculus and the DPRK's position in it. It knows that having China as a powerful patron further narrows any room for South Korean influence on North Korea through soft power.

Therefore, South Korea's soft power is trumped because of the serious consequences that the DPRK's sudden collapse would create for China. Disintegration of the Kim dynasty would result in: (1) short-term destabilization of the region which could lead to a Chinese economic slowdown with potentially long-lasting effects; ; $x i v^{2}$ (2) loss of a buffer zone and the possibility of yet another democratic regime allied with the United States on the Chinese border; ${ }^{x x v}$ and (3) an instantaneous stream of North Korean refugees to China which would also destabilize internal stability. ${ }^{\text {xxvi }}$ Because of these repercussions, abandoning or destabilizing the Kim regime remains a nonstarter for policymakers in Beijing. China's influence remains constrained to attempting to get the DPRK back to the negotiating table. For example, after China cut off oil supplies to Pyongyang in response to the nuclear crisis in August 2003, DPRK's negotiators agreed to participate in three-party talks along with the Unites States. However, the talks did not pass the talking level, demonstrating also the limits of China's influence over North Korea.

In summary, this section of the paper has argued that China's bottom line is saving the North Korean regime and its foreign policy options towards the DPRK remain limited. Maintaining stability on the peninsula, which in effect means perpetuation of the status quo, prevails as the modus operandi for Beijing.

Consequently, China's geostrategic calculations dramatically shrink any room for the exercise of South Korean soft power. Combined with the limits the DPRK's isolationist nature places on the ROK's ability to transmit its soft power, current prospects for this strategy remain bleak. North Korea has successfully built a shield from South Korean soft power with its self-containment and Chinese support.

\section{CONCLUSION}

This paper has argued that South Korea's soft power is inadequate to counter the North Korean threat due to the DPRK's isolated regime and its geopolitical significance to China. As a result, South Korea's soft power has been unable to penetrate the North Korean shield during the transmission and reception phases. This situation is analogous to North Korea having nuclear weapons but without a reli- 
able ballistic system to carry out a long-range attack. Ironically, North and South Korea have been struggling with the same transmission phase for their hard and soft power projection respectively. While South Korea has accumulated significant soft power resources, it continues to lack a functioning delivery system for its soft power to penetrate hostile terrain.

However, this failure should not be regarded as a failure of soft power per se; rather, it is the essence of the objective and the regional context that makes soft power an ineffective solution. Gianni Riotta, member of the Council on Foreign Relations, rightly points out "soft power is like aspirin, great for headaches, less effective against a gunshot wound". To extend Riotta's analogy, South Korea is faced with a "gunshot wound" type problem represented by the DPRK's nuclear threat, but Seoul continues to prescribe "aspirin." This ill-judged diagnosis by the ROK's policymakers -and just as importantly, their inability to deliver effective treatment - results in a neglect of priorities and context on behalf of the ROK's policymakers. Specifically, South Korea's top objective is to denuclearize the Korean Peninsula and reduce hostilities, with future reunification also a goal for many. While nuclear non-proliferation is also a goal for China, maintaining the political status quo in North Korea is an indispensable part of China's foreign policy strategy. China's position and North Korea's isolation together result in the inapplicability of a soft power approach. A solution to the North Korean challenge has not been found yet, but acknowledging policies and operational tools that do not work would be a step in the right direction. 